\title{
HUMOUR, HEALTH AND DISEASE IN MARTIAL ${ }^{1}$
}

\author{
M.J. Mans, University of Pretoria
}

\section{INTRODUCTION}

This article has the twofold purpose of determining by way of thematic systematisation, analysis and interpretation (i) Martial's humoristic treatment of the two motifs, health and disease, and (ii) his aims with them.

Although only a few references to health occur in Martial's epigrams, the importance he attaches to good health and healthy food certainly can not be mistaken or overlooked. In book 6 epigram 70, he stresses the importance of health: non est vivere, sed valere vita est, "(real) life is not just being alive, but to be healthy." For Martial a healthy body is also one of the things that make life happier (Mart. 10.47). Besides, he is well aware of the beneficial qualities of healthy food, such as vegetables and herbs $(11.52 ; 10.48 ; 3.47$; 3.89). It is interesting to note that only once does a healthy person, apparently on account of his health, fall victim to Martial's biting sarcasm, namely in 1.77 , but there, as will be shown below, health per se is merely a point of departure and not the point at issue.

In contrast to the infrequent references to health, however, a thorough analysis of all Martial's epigrams reveals a frequent mention of diseases and ailments, which undoubtedly shows that illness must be a theme of some significance in Martial's poetry. He refers, for example, to the following diseases and ailments: fever, the common cold, infection of the throat, bronchial ailments (inferred from the frequent occurrence of coughing), skin diseases, gout, tooth ache, loose teeth, painful ears, excessive drinking(?), piles, constipation, and physical deformities. Strangely enough, the common headache is not explicitly mentioned in Martial's works; probably because it sometimes forms part and parcel of a fever or a cold. Consequently, amidst this abundance of various diseases and ailments, it comes as no surprise that the medical practitioners are also included in quite a

The text is mainly that of Heraeus' Teubner edition (revised by Borovskij, 1982), except in the case of Mart. 1.65 where in v.2 I accept Caeciliane, (a reading accepted by Lindsay (Oxford edition, 1969), Friedlaender and Ker (Loeb edition, 1979)), instead of Laetiliane (accepted by Heraeus (Borovskij), and Schackleton Bailey). The name Caecilianus occurs in no less than 15 epigrams (cf. Friedlaender 374), whereas Laetilianus does not occur in the text editions of Friedlaender, Lindsay or Ker. As a second possibility for ille in Mart. 10.77.4 (accepted by Lindsay and Heraeus (Borovskij)) I also accept Munro's (and Duff's) suggestion, illa, (Friedlaender, 152). In addition to the above-mentioned text editions, I also used Schackleton Bailey, D.R. (ed. \& trans.) 1993. Martial Epigrams. Vols. 1-III, Cambridge, Massachusetts, London: Harvard University. Press (Loeb Classical Library). Ker's translation was used: the translation of the following epigrams was, however, slightly altered by the present author: $1.10,5.9,6.31,6.70,10.22$, and 11.71 .

I am indebted to my colleagues, Mr. P. Hasse, for his useful comments and suggestions, and Mrs. M.E.B. Martin. for keeping a critical eye on the language. I am also grateful to the referees appointed by Akroterion for their valuable criticism. 
number of his poems. Disease will prove to be a very serviceable and adaptable topic in the hands of an epigrammatist like Martial whose poetry, in his own words, "smacks of man": hominem...sapit (10.4.10). Our epigrammatist wants his reader to identify with life (10.4.11), also to recognise and read of his own manners (8.3.20), and to know himself (10.4.12). He warns against styling his epigrams "only frivolities and quips" (10.49). In 11.17 our poet claims that not every page of his books is for reading at night, but that "you will find, too, what you may read in the morning, Sabinus" (i.e. when you are sober!). With regard to the context of this investigation, however, the most relevant of all Martial's references to his own ars poetica is perhaps the following enunciation of the nature and purpose of his satirical verses, namely: parcere personis, dicere de vitiis, i.e. "to spare the persons, (but) to denounce the vices" (10.33.9-10).

\section{FEIGNING ILLNESS}

The feigning of illness, for various reasons, and especially in the light of the latter quotation from epigram 10.33, comprises a very significant part of Martial's treatment of illness: his ridicule of this whole idea of pretending illness serves a very useful and important purpose, i.e. the unmasking of social evils and phenomena.

By means of a "social" lie a certain Paulus feigns illness to put dinner guests off. Whenever this Paulus is "unwell", Martial tells us in 9.85, he practises abstinence not on himself but on his guests:

Languidior noster si quando est Paulus, Atili, non se, convivas abstinet ille suos. 2

tu languore quidem subito fictoque laboras, sed mea porrexit sportula, Paule, pedes.

Apparently Martial gives Paulus the benefit of the doubt by using quidem ("no doubt") in verse 3. Subito can, however, be interpreted as sarcasm. But it is the somewhat obscured and adversative -que together with the devastating ficto in verse 3 that intensifies our poet's sarcasm when he focusses on this social phenomenon in lines 3-4: "You are suffering, no doubt, Paulus, from a sudden - but fictitious - illness: all the same my dinner has turned up its toes" (is dead and gone), i.e. is lost to me.

Note the clever play on illness and death: Paulus' "indisposition" contrasted with, and thus emphasizing, the death of the dinner-hunter's all-important meal.

Another social lie, occurring in a different, perhaps more physical disguise in 10.22 , is feigning a skin disease to avoid being kissed by the so called basiatores (kissers) (see also Mart. 7.95 and 12.59). Martial gives the following frank answer to his own question:

Cur spleniato saepe prodeam mento

albave pictus sana labra cerussa,

Philaeni, quaeris? basiare te nolo.

"'Why do I often make my appearance with a plastered chin, and my healthy lips painted with white lead?' Do you ask, Philaenus?

'I don't want to kiss you!'"

Although the kissing of hands was practised (Phaedr. 5.8.28; Iuv. 4.117) I suppose the touching of cheeks together, as a substitute for kissing, was unknown in ancient times! Apart from the above mentioned precaution, it seems as though not even skin diseases such as mentagra, dirty scabs, malignant ulcers or inflamed pustules, nor an icicle on a frozen 
nose or fever could protect one from being kissed (11.98). The only remedy for this evil (remedium mali solum), suggested by Martial in 11.98, is to make a friend of someone you don't want to kiss, who, if he is really your friend, will respect your wish not to be kissed: facias amicum basiare quem nolis. 2

In epigram 7.39 the epigrammatist chuckles in his sleeve when he ridicules Caelius who, "when he refused any longer to endure and put up with the various gaddings about, the devious morning calls, and the scornful contempt (disdain) and salutations of wealthy patrons, set up the pretence of gout." He was quite anxious to prove it was genuine, and plastered and bandaged his sound feet, and struggled on with a labouring gait. Apparently with desit fingere in v. 9 Martial does not imply the obvious, namely that Caelius soon realised the folly and futility of his cumbersome attempt, and accordingly stopped feigning gout. A more plausible suggestion seems to be that while he was faking this disease "Caelius - what potency has the exercise and cultivation of affliction! - has ceased to pretend (my italics) gout", not because in the end he has perhaps practically contracted it (this possibility has to be taken into account), but because he couldn't walk normally anymore!:

(quantum cura potest et ars doloris!)

desit fingere Caelius podagram.

This epigrammatic caudal sting is typical of Martial.

In the following three epigrams it becomes evident that bad health is feigned by a wife or a mistress as an excuse for being unavailable. In 11.40 Lupercus tries to cover up for his beautiful mistress, Glycera, whose favours he regrettably has not enjoyed for a whole month. The reason he offers to Aelianus, who asked him, was simply "Glycera had a toothache" (Glycerae dolere dentes) (11.40.6). This excuse reminds one of the hackneyed one offered in modern times "Not tonight, darling, I have a splitting headache"! A second example of a more "serious" nature, i.e. of the pretence of hysteria ${ }^{3}$ arid ill-health as an excuse, is presented by Martial in 11.71.6-8. Leda tells her aged husband that she is suffering in the womb and complains that intercourse is a necessity for her. She also with tears and groans declares that her health is not worth the sacrifice, and that she would rather die. Then her husband pleads with her to live and not to desert the bloom of her years, and comes up with this unusual solution: he permits to be done what he cannot do himself anymore. Laconically Martial concludes:

\section{protinus accedunt medici medicaeque recedunt, tollunturque pedes, o medicina gravis!}

"Immediately men doctors come in, and lady doctors depart, and her feet are hoisted ... Oh, what drastic therapy!"

A third example in 11.7 illustrates an unexpected trait in an unavailable and unfaithful wife - honesty! Every time Pauia wants to go to a lover at a distance she will not pretend the sickness of a friend in order to pay him a "sick-call", because if she offers this feeble excuse to her dull hushand he will cling to her skirts and follow her: aegram simulabis

2 Mart. 11.98; cf. Martial, Epigrams, trans. Walter C.A. Ker, Loeb ed. II, London: W. Heinemann, 1930, n.2, p.307; thoughtfulness for other people's sensitivity to malodorous breath (especially regarding their reluctance to kiss a person with such breath) is clearly illustrated in Mart. 13.18.

3 hysterica: (Gr.: hysterikos -ti -on): (a woman) suffering in the womb. 
amicam?/haerebit dominae vir comes ipse suae, ... Another wanton (of her kind) would perhaps offer the excuse that she is hysterical (i.e. suffering in the womb), and wished to sit in Sinuessa's baths, the waters of which were medicinal (11.7.12). But not Paula. How much better she manages! And here comes Martial's usual and poignant surprise

quanto tu melius, quotiens placet ire fututum, 13 quae verum mavis dicere, Paula, viro!

"Whenever you have a mind to go and have (furtive) sex, Paula, you 'prefer to tell your husband the truth!'"

In one of his epigrams Martial implies that illness can also be abused to show off one's wealth. This message comes through in 2.16 where the bed trappings of the "indisposed" Zoilus get the blame for his fever. In actual fact Zoilus, the exhibitionist, should bear the blame: he tries to make an impression by exhibiting his luxurious bed-trappings, i.e. his wealth (cf. $5.79 ; 3.82 ; 11.37 ; 4.77 ; 11.92$ ). If he were well (which, in fact, he is), scarlet coverlets and a mattress from the Nile or one dipped in strong-smelling purple of Sidon, articles of luxury, would be of no use. In other words, feigning illness offers Zoilus the ideal opportunity of showing off his magnificent coverlets and mattresses. In plain terms Martial advises him:

quid tibi cum medicis? dimitte Machaonas omnis. 5 vis fieri sanus? stragula sume mea.

"What do you want with doctors? Dismiss all your physicians."

Finally he prescribes the right remedy for Zoilus' 'illness' (his exhibitionism, of course):

"Take my (sc. simple) bed-trappings."

Apparently the dispensability and inefficiency of Zoilus' doctors, who dismally failed to diagnose his "illness" correctly, are also insinuated in this epigram.

Captatio is a practice frequently referred to and exposed by Martial, and affords opportunity for some of his most biting sarcasms. Consequently we have Martial here at his best, unmasking this phenomenon as a real social problem! He sometimes enjoys the occasions when the "victims" are able to play off the legacy hunters one against another, and to outwit them (Hull 1967:54), especially by pretending to be ill!

The "hunted" or the "angled for" often become the "hunters" or "anglers" by feigning illness, fooling their doctors, and outmanoeuvring their captatores. It is falsely reported, says our author in 2.40 , that Tongilius is being consumed by a semi-tertian fever: Uri Tongilius male dicitur hemitritaeo. Martial portrays the artful plans of Tongilius imaginatively by using the following very effective metaphors: like a hird-catcher our "patient" Tongilius craftily stretches his nets for the dull-witted thrushes, i.e. the captatores, and like a fisherman lets down his hooks for the mullet and bass, again referring to the legacy-hunters. Vintage wines must be poured for him, and according to his doctors' orders he must take baths. Our poet maintains that there's nothing wrong with him. "Do you think he has fever?" Martial asks. "This is gluttony, you fools!", is his pithy and sharp reply: o stulti, febrem creditis esse? gula est. In other words, Tongilius is hoping for a rich haul of gifts from hopeful legacy hunters (Hull 1967:57). 
Another "patient" and "victim", Parthenopaeus, in order to get the full benefit of honey and nuts, and sweet cakes, prescribed by his doctors for soothing his throat, as well as whatever might stop the fractiousness of boys, feigns a racking, incessant cough. Again Martial caustically concludes epigram 11.86, and in the same manner as in 2.40 above, exposes the so called "patient".

Judging from an analysis of epigram 5.39, it seems as though coughing was the easiest way of pretending illness, because Charinus, when sealing his last will thirty times in a year, received conyratulatory gifts in the form of cakes steeped with Hybla's famous thyme-fed honey. Says the frustrated donor of these gifts:

defeci: miserere iam, Charine, signa rarius, aut semel fac illud, mentitur tua quod subinde tussis. 4

"I am flat broke now, Charinus": you have a choice: "seal your last will less frequently, or do once and for all what your cough constantly suggests falsely": become really ill (and kick the bucket!)

In 10.97 the frustration of a captator whose wings have been clipped by his own "prey" speaks for itself: while his weeping wife was preparing for his funeral, while his funeral pyre was being prepared, and his grave, bier, and anointer all were ready, "Numa wrote me down his heir, and - got well!": heredem scripsit me Numa: convaluit.

Moreover, from the evidence below we infer that the legacy-hunters' pretence of concern about the illness of their "prey" reveals the falseness and true motives of captatores. For his old "friend" who was ill of a severe semi-tertian fever, Maro, a miserly captator, in epigram 12.90 clearly (clare) 5 and publicly (i.e. intended for the patient's ears) made a vow that if the sick man survived, he would sacrifice a victim welcome to mighty Jove. As soon as the doctors begin to guarantee a certain recovery, Maro makes vows in order not to pay his vow! His real vow, i.e. for his "friend's" death, was made under his breath (cf. Pers. ii.8-9; Iuv., xii.98). Perhaps he made vows to another god to ensure that his "prey" kicks the bucket because he felt embarassed to approach Jove again! Thus Maro might kill two birds with one stone: possible exemption from the expenditure on the promised victim, and, even more important, the possibility of receiving his share of his "friend's" legacy!

Pro sene, sed clare, votum Maro fecit amico, cui gravis et fervens hemititraeos erat,

si Stygias aeger non esset missus ad umbras, ut caderet magno victima grata lovi.

coeperunt certam medici spondere salutem. ne votum solvat nunc Maro vota facit.

The same message, namely that some captatores are outmanoeuvred by their "prey", this time definitely more explicit and frank, but not as striking as the previous suggestion, is also communicated in 12.56.4: sit pudor: aegrota iam, Polycharme, semel, "be ashamed: now be ill, Polycharmus, once for ail."

5 I.e. that it should be reported to the sick man; or perhaps this was his public vow, his real vow for the patient's death being under his breath: cf. Pers. vii. 8; Iuv. xii.98. 
The following epigram, 1.10, is a real gem. Let Martial in his own words unmask the false motives of this particular captator:

Petit Gemellus nuptias Maronillae et cupit et instat et precatur et donat.

Adeone pulchra est? Immo foedius nil est. Quid ergo in illa petitur et placet? Tussit.

"Gemellus wants to narry Maronilla; he desires it, he urges her, he implores her, and sends her gifts. Is she so beautiful? Nay, no creature is more disgusting. What then is the bait and charm in her? She coughs."6

In 8.25 it becomes evident that the captatores' visits could be detrimental to the health of patients. Martial complains that Oppianus 7 came to see him once only when he was ill. The two words semel and tantum express the poet's true perception of these false legacyhunters. Wittily the author, without mincing matters, reprimands this legacy-hunter: "It will be to my misfortune if I see you often, Oppianus. ": male saepe te videbo (Cf. 5.9).

\section{MARTIAL USES ILLNESS AND HEALTH TO DRAW ATTENTION TO OTHER SOCIAL EVILS AND PHENOMENA}

He uses gout, for example, to focus on miserliness. Note how cleverly Martial in 1.98 transfers the disease from Diodorus' feet to his hand to suggest the miserliness, and unwillingness of the man to open his hand and pay for services rendered:

Litigat et podagra Diodorus, Flacce, laborat. sed nil patrono porrigit: haec cheragra est.

"Diodorus goes to law, Flaccus, and suffers, from gout in the feet. But he offers his advocate no fee: this is gout in the hand."

A most enjoyable unmasking of stinginess!

The acquisition of immunity against deadly drugs is used by Martial to expose cheeseparing. A subsidiary method of alleviating poverty, and appeasing hunger, was to try to elicit frequent invitations to dinner, and thus cut the cost of living at home. This is simply another form of parasitism and was no doubt practised by the same people along with clientship and legacy-hunting (Hull 1967:59-60). It is, however, on miserliness, and not on

6 See also Mart. 10.8; cf. 6.63.1-4: there is no evidence in this epigram that Marianus is ill and that munera specifically means "congratulatory gifts" to him "for recovering his health": Munera magna tamen misit.

7 Since Martial died in c. 104 A.D., his choice of the name "Oppianus" can not possibly be connected to the two Greek poets who wrote under the same name, but lived in the second and third centuries A.D. respectively. The first Oppianus lived about A.D. 180-182 and wrote the Halieutica, a poem on angling. The second one lived circa 206 A.D. and composed the Cynegetica, a poem on hunting. Cf. $C O D^{2} 753$; W. Smith, Smaller Classical Dictionary, p. 415 . 
this kind of parasitism, that Martial focusses in 5.76:

Profecit poto Mithridates8 saepe veneno toxica ne possent saeva nocere sibi.

tu quoque cavisti cenando tam male semper ne possis umquam, Cinna, perire fame.

"Mithridates, by often drinking poison, achieved protection against deadly drugs. You too, Cirna, have taken care, by always dining so meagrely, against ever perishing of hunger."

Contrary to expectation Martial, in conclusion, maintains that Cinna's precaution, i.e. his regularly meagre meals (instead of having a detrimental effect on his stomach and general health), makes him used to scanty meals and immune to starvation! The prominent position of fame and its consequent effect is noteworthy!

In our introduction mention was made of the fact that Martial uses a healthy person, a certain Charinus, in 1.77 as the object of his satirical attack on the latter's indulgence in debauchery, and not, as can be inferred from the contents, to ridicule health per se. He says:

"Charinus has good health, and yet he is pale.

Charinus drinks moderately, and yet he is pale.

Charinus has good digestion, and yet he is pale.

Charinus enjoys the sunshine, and yet he is pale.

Charinus rouges his skin, and yet he is pale."

Martial concludes in verse 6 that Charinus indulges in oral sex - and yet/therefore he is pale.

Pulchre valet Charinus et tamen pallet.

parce bibit Charinus et tamen pallet.

bene concoquit Charinus et tamen pallet.

sole utitur Charinus et tamen pallet.

tinguit cutem Charinus et tamen pallet.

cunnum Charinus lingit et tamen pallet.

There are three possible explanations to be offered for Charinus' pallor: (i) a physical cause: good health, moderate drinking, good digestion, sunshine, and rouge are supposed to bring a blush to his cheeks. He is, however, pallid by nature. Consequently he does not even blush though the physical excitement of debauchery is supposed to send the blood rushing to his face (ii) his unscrupulousness: morally speaking he has no conscience at all and commits obscenities without even blushing (or, most probably, without batting an eyelid), and (iii) the physical exhaustion of debauchery, i.e. the concluding activity in the epigram (even though it may be exciting), causes his paleness and suggests his weakness and "sickness"! In my opinion this is the reason Martial actually has in mind. The frequent and regular use of "et tamen" enhances the paradoxical joke. Moreover, the concluding "et tamen" might even be translated as "and therefore", emphasizing that his pallor is the direct result of his obscene activity.

8 Mithridates "the Great", when driven to bay, found that a diet of prophylactics had made him immune to poison, $C O D^{2} 696$. 
The epiphoric use of the verb pallet, occurring no less than six times in successive verses, and strikingly and constantly placed at the end of each line, throughout the entire poem, very effectively accentuates Charinus' pallor. To my mind the antithesis health - pallor is successfully used to draw attention to indulgence in debauchery.

A social evil of a less serious degree, but still very troublesome and annoying, is the social phenomenon of pestilently loquacious men, who, in spite of having a cold or a fever, being most desirous of speaking to their reluctant audience, make themselves extremely unpopular in Martial's time by carrying on regardless.

In the following four very short epigrams Martial strikes out at these social pests. In 4.80 he declares:

... cum viscera febris 5

"When fever burns up your vitals 'tis a great thing to hold your tongue, Maron."

In 3.18 Martial once more rebukes the eager recitator with a cold in his throat. Again in 6.41 he states:

Qui recitat lana fauces et colla revinctus, hic se posse loqui, posse tacere negat.

"He who recites with throat and neck wrapped up in wool declares that he can neither speak nor shut up."

This statement apparently sounds like a contradiction in terms, but it is merely Martial's skilful way of antithetically and humorously implying that the prospective reciter ought to shut up and refrain from reciting!.

And finally he castigates these pests again in 4.41 :

Quid recitaturus circumdas vellera collo? conveniunt nostris auribus ista magis.

"Why when about to recite, do you put a muffler round your neck? That is more suitable to our ears!"

\section{MEDICAL PRACTITIONERS}

The Romans' antagonism, malicious prejudice against, and distrust in medical practitioners; the latter's inefficiency, low status, dispensability, and unethical conduct are illustrated in the epigrams discussed below.

Cato the Censor, (Pliny Nat. Hist. 29.14; Paoli 1977:213) animated by a furious hatred of professional doctors (Paoli 1977:213, 210), boasted that he had reached a vigorous old age by the judicious use of his own remedies (Paoli 1977:210). The suspect skill and foreign origin surrounded the doctors in ancient Rome with distrust (Paoli 1977:213). "They have conspired to kill us all", wrote Cato (Pliny Nat. Hist.29.14; Paoli 1977:213), "and they charge a fee for it, so that they may be trusted and easily destroy us" (Paoli 1977:213). The prejudice against doctors in Rome never completely disappeared, because it was not always easy to distinguish between the man of science and the charlatan (Paoli 1977:214). 
Cicero ranked them next to architects and teachers (Cicero De Off. 1, 42.151), Varro to dyers and blacksmiths (Varro De Rustica 1.16.4).

It is assumed that Carus was a specialist in quartan fever (Friedlaender 1967:152). Therefore his dying of a fatal fever was scandalous, according to Martial in 10.77; and caused an outrage. Consequently our poet somewhat maliciously declares: the cruel, fatal fever should have been at least a quartan, a less fatal ailment, which, of course, offers the prospect of prolonged suffering! This is the kind of malady that should have been reserved for its own doctor. On the other hand, if we accept the reading ille insteall of illa in v.4, then the meaning could also be that the disease should have taken the mild form of a quartan,9 leaving enough time for the patient to be treated, i.e. in a worse way, and eventually "tortured" to death, by his own doctor!10:

Nequius a Caro nihil umquam, Maxime, factum est quam quod febre perit: fecit et illa nefas.

saeva nocens febris saltem quartana fuisset:

servari medico debuit illa [ille] suo.

Like Cato the Censor (Pliny Nat. Hist. 29.14; Paoli 1977:210, 213), and in accordance with the antagonism against medical practitioners mentioned above, Martial definitely also did not have a very high opinion of the ability of the doctors of his time. This becomes evident from numerous epigrams in which he ridicules the inefficiency of medical practitioners. In 8.74 we are informed that a former eye-specialist is an oplomachus now, i.e. a heavily armed gladiator. Obviously attempting to equalize the professions of gladiators and eye-specialists, our epigrammatist wittily remarks that the eye-specialist did as doctor what he does now as well-trained, heavily armed gladiator, namely to wound, i.e. to blind his opponent and or patient.

Oplomachus nunc es, fueras opthalmicus ante. fecisti medicus quod facis oplomachus.

It seems as though Martial can not stop depreciating the importance and value of the medical practitioners of his day: in two almost identical epigrams, 1.47 and 1.30, he subtly, but mockingly, degrades the doctor to the level of the undertaker:

Nuper erat medicus, nunc est vispillo Diaulus: quod vispillo facit, fecerat et medicus.

"Lately Diaulus was a doctor, now he is an undertaker. What the undertaker now does the doctor too did before."

The latter insinuation is more explicitly and punningly elucidated in 1.30.2: he begins to be a bearer of the bier in his old effective way!: "coepit quo poterat clinicus esse modo." The pun, of course, lies in the ambiguity of clinicus, namely that in this context the word clearly does not mean a physician, but refers to a bearer of the bier! (cf. 3.93.24). In other

9 Cf. Iuv. 4.57: "And now death-bearing Autumn was giving way before the frosts, fevered patients were hoping for a quartan". (A quartan is a fever recurring every fourth day - an improvement upon a "tertian", one recurring every third day - and therefore less fatal.)

10 I arrived at this particular interpretation before (only recently) Schackleton Bailey's (new) translation has been made available to me; cf. pp.395-397 in his Loeb edition (1993); cf. Friedlaender, 152; Ker, Loeb ed. II, n.1, pp.214-215. 
words, Diaulus now lays out the corpses in the same way he used to put his patients to "bed" (bier!) as a doctor!

Supporting evidence of patients dying under operations is found in Roman epitaphs, and their mortality rate is also confirmed by luvenal.11

The medical attendance of Martial's doctor, Symmachus, although he attended the poet promptly when he became ill, is, however, severely criticised. The reason for this sharp, and somewhat unexpected criticism is to be found in the following scene vividly described by Martial in 5.9:

Languebam: sed tu comitatus protinus ad me venisti centum, Symmache, discipulis.

Centum me tetigere manus Aquilone gelatae; non habui febrem, Symmache: nunc habeo.

"I was showing symptoms of illness; but you at once attended me, Symmachus, with a train of a hundred apprentices. A hundred hands frosted by the North wind have pawed me: I had no fever before, Symmachus; now I have!"

From the evidence above it can therefore be inferred that doctors' treatment or visits could be detrimental, even fatal to patients' health!

The following anecdote occurring in epigram 6.53 illustrates the negative and prejudiced perception of the efficiency of medical doctors in first century Rome and the frightening image they projected. Our poet tells us the story of a certain Andragoras who bathed with his friends, had a cheerful dinner, and nevertheless was found dead in the morning (cf. also Anth. Pal. $11.257 ; 118$ ). As usual Martial surprises us and gives the following pithy explanation for such a sudden and unexpected death:

in somnis medicum viderat Hermocraten.

"He had in a dream seen (his) doctor Hermocrates!"

Were medical practitioners regarded by the ancient Romans as dispensable? Judging from the evidence above, the answer to this question would seem to be a detinite affirmative. Apparently Cato the Censor was not the only Roman of this conviction (Pliny Nat. Hist. 29.14; Paoli 1977:210, 213-214). Although Cicero described their skill as "sensible and useful" (Cic. De Off. 1.42.151; cf. Paoli 1977:214) it becomes clear in 6.70.4-6 that Martial sympathetically permits Cotta, who cannot recall that even for a single day he has

11 H. Geist (G. Pfohl), Römische Grabinschriften, Ernst Heimeran Verlag, München 1969, p. 105, nr.273: Anima innocentissima, quem medici secarunt et occiderunt: "Unschuldige Seele; ihn haben die Ärzte operiert und umgebracht": this phenomenon (i.e. the mortality rate of patients dying under operation) is confirmed by Iuvenal (Sat. 10.221) as follows:

...morborum omne genus, quorum si nomina quaeras,

promptius expediam quot amaverit Oppia moechos,

quot Themison aegros autumno occiderit uno,

"... diseases of every kind dance around him in a troop; if you ask of me their names,

I could more readily tell you the number of Oppia's paramours,

how many patients Themison killed in one autumn, ..." 
felt the weariness of a fevered bed, to point the insulting finger, i.e. the middle finger, scornfully at Alcon, Dasius and Symmachus, all three of them doctors:

nec se taedia lectuli calentis

expertum meminit die vel uno.

ostendit digitum, sed inpudicum,

Alconti Dasioque Symmachoque.

Presumably implying with this scornful gesture that he became 62 years old and up to now enjoyed a healthy life without the aid of any medical practitioner and that he only has contempt for their inefficiency! (Cf. Mart. 2.16).

Doctors' unethical conduct is also touched upon by the poet. Baccara, a Raetian, entrusted the care of his organ to a doctor who was his rival in love. This proves to be a costly mistake because Martial quickly, frankly and punningly tells us Baccara will now become a Gallus, meaning, of course, not a Gaul but a eunuch! Gallus refers to the priests of Cybele who were eunuchs. This unethical deed is satirized in 11.7412:

\section{Curandum penem commisit Baccara Raetus rivali medico. Baccara Gallus erit.}

Yet another example of misconduct occurs in 6.31 where we learn that Charidemus' doctor is having an affair with his wife. This is how our epigrammatist in his own words ridicules the whole affair: "You are quite aware, Charidemus, of your doctor's misconduct with your wife, and you wink at it. It is not by fever that you want to die" - but by poison (that could, of course, be administered to him by either his doctor or perhaps even his own wife!) Martial seems to suggest! (Mart. 6.31; Friedlaender 1967:444; Ker 1979: Vol. I, n.1, p.376):

\section{Uxorem, Charideme, tuam scis ipse sinisque a medico futui. vis sine febre mori.}

Or does Charidemus shut his eyes to the current affair deliberately, because he wants to ensure medical treatment (by his medicus and rival in love) for his fever, and, consequently desires to die of age eventually?

In the next few poems the poet deals with doctors and the consumption of alcohol by their patients. Judging from evidence found in Horace there were doctors who cared for their patients (Hor. Ep. 1.8.9; Id. Sat. 2.3.147). In Martial's epigrams we also find confirmation of this when he mentions physicians who showed concern for their patients and forbad them to drink wine (6.86). One such caring(?) physician, doctor Herodus, is introduced to us in 9.96 . Whether this is a positive note sounded by Martial, resulting from a change of attitude towards doctors, is questionable.

This doctor had stolen a drinking-ladle from a sick patient. When he was detected he quickly turned defence into attack and aggressively asked his patient the following question: "You fool. why then do you drink?" ("Stulte, quid ergo bibis?"), as if he was professing care for his patient's health hy removing the article (Ker 1978: Vol. II, n.5, p.143).

12 Cf. $C O D^{2}$ 416; Mart. 2.45; Schackleton Bailey, 1993: Vol. II, note b, 167; cf. also Ker, 1979: Vol. I, n.3, p.51; and n.2, p.179. 
It can be inferred from epigram 5.4 that heavy drinking, especially by women, was not always acceptable in social circles (Paoli 1977:113), and frowned upon even in Martial's time. 13

Further evidence that medical practitioners warned against drinking is found in 6.78 in the following humorous anecdote. Phryx, a notorious tippler, who was blind of one eye, and blear-eyed in the other, received the following warning from his doctor: ... "Bibas caveto:/vinum si biberis, nihil videbis", i.e. "beware of drinking: if you drink wine you will not see at all." In spite of his physician's warning, Phryx jokingly bade his eye farewell and drank excessively. Martial humours this fictitious drinker in his typical epigrammatic and devastating way and presents us with the following poignant surprise in the concluding verses: "exitum requiris?/vinum Phryx, oculus bibit venenum", "Do you ask the result? Phryx drank a vintage, his eye venom."

\section{SOME "ADVICE" ON PERSONAL HYGIENE}

In 14.51 it seems as though Martial gives the following advice: keep your body clean, but, contrary to what the reader may expect, namely that personal hygiene is beneficial to one's general health, his advice proves to be a very prosaic and most practical hint: your towels will last longer! This advice is tersely and humourously expressed as follows:

Pergamon has misit. curvo destringere ferro:

non tam saepe teret lintea fullo tibi.

"Pergamus has sent these strigils: scrape yourself with the curved blade: the laundryman will not so often wear out your towels". 14

\section{PHYSICAL DEFECTS AND HANDICAPS}

In spite of the already existing luxury of a wig in Martial's time, a poor consolation though for baldness, (Mart. 12.89; cf. Paoli, 1977:111, 212-213) Charinus still seems to try and conceal his bald pate by swathing his head in wool. In epigram 12.89, however, Martial quickly exposes this pretence:

non aures tibi sed dolent capilli.

"...it is not with your ears that it goes sadly, but with your hair.".

It is difficult to imagine that a sensory defect can be an asset, can ensure a safe investment and can even send the purchase price of a slave or mule-driver soaring! But it did happen in Rome and, of course, Martial humourously uncovers this unusual phenomenon in 11.38:

13 "Myrtale is apt to reek with much wine, but to mislead us, she devours laurel leaves and mixes her neat liquor with this canny foliage (Shackleton Bailey I, 355), not with water." Martial clarifies the use of laurel leaves as follows: as often as you see her, Paulus, flushed and with swollen veins, coming towards you, you may say: "Myrtale has drunk the laurel," i.e. is inspired. The priestess of Apollo at Delphi chewed laurel-leaves to acquire inspiration (Tib. 2.5.63; Iuv. 7.19; $C O D^{2}$ 323; Ker 1978: Vol. II, 397).

14 I.e. they will not be sent to him so dirty! (Mart. 14.51; cf. Ker 1978: Vol. II, n.1, p.458; Mart. 10.11.6). 
Mulio viginti venit modo milibus, Aule.

miraris pretium tam grave? surdus erat.

"A mule-driver was lately sold, Aulus, for twenty thousand sesterces. Do you wonder at so heavy a price? He was deaf."

Martial leaves the fact that the mule-driver fortunately could not hear the confidential conversation of those in his master's carriage entirely to the reader's imaginative supposition (Cf. Mart. 12, 24.8).

In epigram 10.100 Martial skilfully employs a bodily handicap as a literary means of expression. Don't try and sponge on someone with real talent if you yourself don't even have half as much, in other words, don't be guilty of literary piracy - your attempt will be in vain. This is about as prosaic a summary of the contents of this epigram as one can get. In epigrammatic mould, however, the striking-power of the humorous way of expressing this simple truth, by means of a physical handicap, has a literary force and charm of its own:

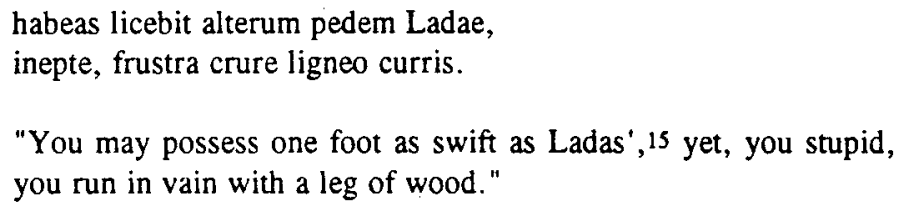

Martial is sometimes at his best in his shortest epigrams. Those carrying the theme of a physical handicap are no exception, for example 3.8:

"Thaida Quintus amat." "Quam Thaida?" "Thaida luscam."

unum oculum Thais non habet, ille duos.

"'Quintus loves Thais.' 'Which Thais?' 'Thais, the one-eyed.'

Thais lacks one eye, Quintus both."

The same theme of "blind" lovers repeats itself more or less in $3.15,8.49$, and 3.39.

Epigram 4.65 also serves as a good example:

Oculo Philaenis semper altero plorat.

quo fiat istud quaeritis modo? lusca est.

"Philaenis always weeps with one eye. Do you ask how that happens? She is one-eyed."

Compared to Martial's usage of a disease, namely gout, in unmasking miserliness in 7.39 , our poet, with even greater literary success, uses physical deformity as a means to expose stinginess in 8.9: when Hylas was blear-eyed, quite recently he was still willing to pay Quintus three-quarters of his debt. Now that he is one-eyed he is willing to give only half. Hopefully Quintus followed the following sound advice given by Martial:

accipe quam primum; brevis est occasio lucri:

si fuerit caecus, nil tibi solvet Hylas.

15 A celebrated Spartan nunner, and winner at Olympia: Der Kleine Pauly 440; cf. Mart. 2.86.8. 
"Take it at once: brief is the opportunity for gain; if Hylas becomes blind, he won't pay you a penny."

\section{LOOSE TEETH AND TOOTHLESSNESS}

In the hands of an epigrammatist of Martial's calibre toothlessness 16 offers an ideal subject for ridicule (Cf. Mart. 2.41). He definitely does not disappoint his audience with his literary deftness in this regard as is clearly illustrated in 1.19, and 8.57:

Aelia had four teeth. Our poet tersely and mockingly suggests that her teeth were dangerously loose and simultaneously implies that misfortunes never come singly. In Martial's own words, here's what happened to poor Aelia's teeth:

expulit una duos tussis et una duos.

iam secura potes totis tussire diebus:

nil istic quod agat tertia tussis habet.

"one fit of coughing shot out two, and another two more. Now in peace you can cough all day: a third fit has nothing left to discharge."

Then there is the anecdote of Picens who had only three teeth. As he was sitting by his own tomb he spat out all three at once. He then gathered up in his lap the "latest fragments of his loosened jaws" and "entombed" them in the piled-up earth. Martial's concluding remark in 8.57 is suggestive of someone with his one foot in the grave:

ossa licet quondam defuncti non legat heres:

hoc sibi iam Picens praestitit officium.

"Some day his heir need not collect the dead man's bones: that office Picens has already performed for himself."

\section{PILES}

After Martial and Caecilianus had bickered over the right word for figs and could not come to an agreement whether it should be "ficus" (fourth declension) or "ficos" (second declension), Martial apparently became vexed with Caecilianus' pettiness. Needless to say, he had the best of the argument and this is how in 1.65 he words his satirical version of the problem that gave rise to their quarrel:

Cum dixi ficus, rides quasi barbara verba et dici ficos, Caeciliane, iubes.

"When I called figs 'ficus' you laughed at it as an outlandish word, and you require them to be called 'ficos'."

16 Warm vinegar and sugar made loose teeth firmer. So Pliny tells us (Nat. Hist. 20.15). But when, in spite of all precautions taken, the teeth loosen further, they may even fall out. The loosening of teeth, we now know, of course, is caused by pyorrhoea and infection in the roots of the teeth as a result of neglecting mouth hygiene. 
Martial has the following solution to their problem:

dicemus ficus, quas scimus in arbore nasci, dicemus ficos, Caeciliane, tuos. 17

"We will call those 'ficus' which we know grow on a tree; we will call your figs (i.e. haemorrhoids), Caecilianus, 'ficos'."

\section{CONSTIPATION}

In our introduction mention was made of Martial's awareness of the benefits of healthy food. In the following epigrams he recommends vegetables and herbs to avoid constipation. In 11.52 he regards lettuce as "useful for relaxing the bowels..." (Cf. Mart. 13.14), "and not unserviceable to a sluggish stomach ..." in 3.47. He also believes that mallows "will unload the stomach ..." (10.48). But in 3.89 Martial wants to share the healthy qualities of lettuce and mallows with Phoebus, because he thinks he (Phoebus) is in dire need of it:

Utere lactucis et mollibus utere malvis:

nam faciem durum, Phoebe, cacantis habes. 18

"Take lettuces and take aperient mallows, for you have the straining appearance, Phoebus, of one suffering from constipation."

\section{CONCLUSION}

Without proclaiming it explicitly, Martial evidently focusses his attention rather on illhealth than on health, because each and every one of these diseases offers more sensation, greater variety, a wider scope, and, of course, more striking-power for his literary purpose. Their many-faceted characieristics are copiously and effectively used by our poet in ridiculing some or other social evil (10.33). In this way disease is given a special literary importance of considerable effect. This motif in Martial's epigrams either carries the theme or helps to promote its elaboration.

True to the typical Roman malice, the real Italum acetum can be discerned in his epigrams when he bitingly, even at times maliciously, calls a spade a spade. Rudeness has no point in it unless it is barbed. The functions of his humour are mainly communicative and psychological in nature. It communicates a message to his readers, usually of a serious nature (Mart. 11.17; 10.49). It not only causes its target embarrassment, but also concerns itself with providing man with a mirror in which he can recognise his own manners and get to know himself ( $\mathrm{Cf} .10 .4 ; 8.3$ ). His greatest success is achieved in utilizing the feigning of illness, because, inter alia, he most effectively and exhaustively exposes the corrupt captatio. With the aid of disease as a literary topic he also very successfully draws our attention to the inefficiency and dispensability of medical practitioners. Psychologically speaking, his humour lightens the heaviness related to illness, physical deformities, and

17 Martial's other puns on the same subject, to be found in $7.71,4.52$, and 14.86, are rather cumbrous.

18 It is interesting to note that the same cast of countenance, ridiculed above, was ascribed to the Emperor Vespasian by Suetonius: Vesp. 20: "he was well built, with strong, sturdy limbs, and the expression of one who was straining." (Ker Loeb I, n.3, p.219). 
death. Martial succeeds in drawing his audience's attention away from the painful reality of illness by simultaneously ridiculing, and effectively exposing social evils. The subjects of his satirical epigrams may be fictitious, but everybody can recognise old acquaintances in them, identify with them and with life (Mart. 8.3; 10.4.10-12), and laugh at them with his friends with many a sly wink (Paoli 1977:276). As a literary topic and instrument in the hands of a skilled and renowned epigrammatist like Martial, disease and ailment, in the way the latter is exploited in his poetry, proves itself to be in accordance with the proclaimed general nature of his epigrams in 10.33 , namely to denounce society's vitia, but to veil the identity of the cuiprits:

\section{hunc servare modum nostri novere libelli, parcere personis, dicere de vitiis.}

Martial can not be labelled as a self-proclaimed guardian of morals. Nevertheless, the fact that in the quotation above he uses the word vitia, i.e. vices, moral faults or imperfections, supports our -argument, based on the evidence presented above, that he certainly, and intentionally, with a strong, prevailing sense of humour, uses disease as a literary aid not only to unveil certain vitia such as the social (white?) lie, spouses' and lovers' unavailability (and unfaithfuiness?), the captatio, miserliness, loquaciousness, and exhibitionism, but also to turn the full glare of the public eye to the inefficiency and dispensability of medical practitioners.

\section{BIBLIOGRAPHY}

Friedlaender, L. (ed.) 1967. M. Valerii Martialis Epigrammaton Libri. Amsterdam: Hakkert.

Heraeus, W. (ed.) 1982. M. Valerii Martialis Epigrammaton Libri (editionem correctiorem curavit Iacobus Borovskij). Leipzig: Teubner Verlagsgesellschaft (Bibliotheca Scriptorum Graecorum et Romanorum Teubneriana).

Hull, K.W.D. 1967. Martial and his times. London: G. Bell and Sons.

Ker, Walter C.A. (ed.) 1978. Martial Epigrams. Vol. II, London: William Heinemann (Loeb Classical Library).

Ker, Walter C.A. (ed.) 1979. Martial Epigrams. Vol. I, London: William Heinemann (Loeb Classical Library).

Lindsay, W.M. (ed.) 1969. M. Valerii Martialis Epigrammata Libri. Oxford: Clarendon (Scriptorum Classicorum Bibliotheca Oxoniensis.)

Paoli, U.E. 1977. Rome its people life and customs. London: Longman.

Schackleton Bailey, D.R. (ed. \& trans.) 1993. Martial Epigrams. Vols. I, II and III. London: Harvard University Press (Loeb Classical Library). 